\title{
THE ADOPTION STAGES OF MOBILE NAVIGATION TECHNOLOGY WAZE APP AS JAKARTA TRAFFIC JAM SOLUTION
}

Noni Noerkaisar Student of Graduate Program of Management and Business, Bogor Agricultural University, Indonesia E-mail: noninoerkaisar@gmail.com

Budi Suharjo Department of Statistic, Faculty of Mathematics and Natural

Science, Bogor Agricultural University, Indonesia E-mail: budi.suharjo2010@gmail.com

Lilik Noor Yuliati Department of Family and Consumer Sciences, Faculty of Human Ecology, Bogor Agricultural University, Indonesia E-mail: lilik_noor@yahoo.co.id

Submission: $24 / 03 / 2016$

Resubmit: 07/04/2016

\section{ABSTRACT}

Accept: 13/04/2016

This study analyzes the adoption stages of Waze mobile navigation by using a hierarchy of effects models AIDA. Data were obtained through the survey method by means of direct interview using questionnaire instrument assistance. The results showed that there were two groups, one who have already used the Waze application and the other who have not yet used Waze application. The two groups were analyzed to see a series of Waze application adoption process. It can be seen that each stage in the adoption process affects each other. The interest of respondents to the Waze app is affected by the strengthening of awareness regarding the benefits offered by mobile navigation app Waze. The high interest of resondents continues to stage where the respondents are interested in using Waze application. At the final stage it is known that the 
DOI: 10.14807/ijmp.v7i3.447

majority of respondents who were exposed to information on uses and functions of the application Waze are willing to immediately adopt the Waze app as a mobile navigation application while driving.

Keywords: Adoption process, Mobile navigation technology, AIDA model

\section{INTRODUCTION}

This template, modified in MS Word 2003 and saved as "Word 97-2003 \& 6.0/95 - RTF" for the PC, provides authors with most of the formatting specifications needed for preparing electronic versions of their papers. All standard paper components have been specified for three reasons: (1) ease of use when formatting individual papers, (2) automatic compliance to electronic requirements that facilitate the concurrent or later production of electronic products, and (3) conformity of style throughout a papers. Margins, column widths, line spacing, and type styles are builtin; examples of the type styles are provided throughout this document and are identified in italic type, within parentheses, following the example. Some components, such as multi-leveled equations, graphics, and tables are not prescribed, although the various table text styles are provided. The formatter will need to create these components, incorporating the applicable criteria that follow.

Jakarta as the Capital of Indonesia, which became the center of government and economic center, has a great appeal for many people to come to Jakarta. Every day hundreds even thousands of people from the outskirts of Jakarta (Bogor, Depok Tangerang, and Bekasi) come to Jakarta by private vehicle. According to data from the Jabodetabek Public Transportation Policy Implementation Strategy, the number of trips that go to Jakarta were 18.77 million trips per day in 2014. Based on that number, $98 \%$ of them used private vehicles such as cars and motorcycles, and only $2 \%$ used public transportation.

Decreased interest in public transportation is caused by many factors, one of them due to the massive motorization, even higher than before the crisis occurred, i.e. an increase of $16 \%-18 \%$ per year (SUTOMO, 2008). Moreover Sutomo (2008) suggested other condition that lower the interest in using public transportation is the inconvenience of public transportation, both poor maintenance and security issues. The rising increase in the number of private vehicles and the unbalanced growth of 
DOI: 10.14807/ijmp.v7i3.447

the road network became great contributing factors to congestion in Jakarta (HENDRATNO, 2009).

Jakarta Provincial Government has done several ways to solve traffic congestion in Jakarta. One way that is currently done by Jakarta Provincial Government to tackle congestion is to optimize the use of media and technology infrastructure or the so-called Information and communication Technology (ICT). Utilization of ICT media was selected based on the high number of Internet users in Indonesia, which is based on the domicile $78.5 \%$ live in the western part of Indonesia and are dominated by the urban community (APJII, 2014).

Navigation based global positioning system (GPS) systems is an ICT media used by the city government as a solution to overcome traffic congestion in Jakarta. The main obstacle in urban navigation system in Indonesia, especially in Jakarta, is the base map. The completeness and accuracy of base map highly depend on the recency of the information provided (AGUSTAN, 2008). Therefore, the city government cooperates with Google through Waze app as a mobile navigation system that can provide information on cutting-edge map.

Waze app has an innovation that allows users to update the map, so that the information obtained has greater accuracy and can shorten the distance. In contrast to other navigation applications, application Waze is a social community-based navigation application. Waze app connects users to be able to interact and share information on traffic conditions around so the information obtained is actual and accurate. The more people use Waze application as an application navigation while driving of course the more accurate the information obtained.

The novelty of an innovation is reflected in the knowledge, attitudes, and a person's decision to adopt (LESTARI 2012). Some people will soon adopt or accept an innovation as soon as they know it, while others need more time to try something new, while the other group again need that much longer time, and so on (MORISSAN; WARDHANI; HAMID, 2013). Same things happen in adopting the Waze app, some people may directly use Waze app while driving when they hear information regarding mobile navigation app Waze. While the others require a long time to be able to adopt the Waze application even though they has heard about the mobile navigation app Waze. 
DOI: 10.14807/ijmp.v7i3.447

The individual reaction stages towards an innovation will lead to a certain action and behavior change (HASAN, 2012). Hierarchy of effect is a linear theory of marketing and advertising which presumes that consumers must go through a rational and sequential series of steps that ends up in steps such as, attention, interest, desire and purchase decision (GROVER; VRIENS, 2006). An important hierarchy models is the AIDA model which describes four stages that the advertising drives the consumer into, starting with awareness, interest, desire and finally action (GHIRVU; 2013; BELCH; BELCH, 2009; WHITE, 2000; REHMAN; NAWAZ; ILYAS; HYDER, 2014). This models is a guideline for marketers to reach potential consumers and 'help' the potential consumer in the process from unaware consumer to Purchaser of a certain product (MOOIJ, 2010).

Based on the background of the problems mentioned, the purpose of this study is to analyze the stages of the process of adoption of mobile navigation Waze starting from public awareness of the Waze app. And then continue to the stage of interest and the public interest to use the Waze app. The final stages of the adoption process circuit is the community's decision to use the Waze app.

\section{METHOD}

The respondents were 200 people, drawn from the population of people who commute by motor vehicles in Jakarta. Respondents were selected by convenience sampling method. Interviews with the aid of questionnaire instrument were done to 50 respondents in every region of the Central Business District (CBD) Jakarta including; Gatot Subroto street, Sudirman street, M.H Thamrin street and Kuningan street. CBD area was selected based on data issued by the Department of Transportation referring to the results of the study Study on Integrated Transportation Master Plan for Jabodetabek (SITRAMP) in 2004 that the distribution of Gatot Subroto street, Sudirman street, MH Thamrin street and Kuningan street are included in the zone with The highest volume of private vehicles.

\section{RESULTS}

\subsection{Characteristics of Respondents}

The demographic characteristics of the respondents in this study is divided into several criteria including gender, age, education level, occupation, and domicile (Table 1). 
INDEPENDENT JOURNAL OF MANAGEMENT \& PRODUCTION (IJM\&P)

http://www.ijmp.jor.br

v. 7, n. 3, July - September 2016

ISSN: 2236-269X

DOI: 10.14807/ijmp.v7i3.447

Table 1: Characteristics of Respondents

\begin{tabular}{llcc}
\hline Categories & Criteria & Frequency & Percentage (\%) \\
\hline \multirow{2}{*}{ Gender } & Male & 70 & 35 \\
& Female & 130 & 65 \\
Age & $18-27$ years old & 154 & 77 \\
& $28-36$ years old & 26 & 13 \\
Level of & $37-45$ years old & 20 & 10 \\
education & Senior high school & 22 & 11 \\
& Diploma & 10 & 5 \\
& Bachelor & 144 & 72 \\
& Postgraduate & 24 & 12 \\
& Civil servants & 14 & 7 \\
\multirow{4}{*}{ Type of work } & State-Owned Enterprises & 34 & 17 \\
& Employee & 84 & 42 \\
& Professional & (Lawyer, & 3 \\
& others) & 6 & 7 \\
& Entrepreneur & 14 & 18 \\
& Student & 36 & 6 \\
& Others & 12 & 49 \\
& Jakarta & 98 & 25 \\
Domicile & Bogor & 50 & 8 \\
& Depok & 16 & 7 \\
& Tanggerang & 14 & 11 \\
\hline
\end{tabular}

The survey results showed that the gender composition is dominated by women respondents, which is $63 \%$. The majority of respondents were in the age range of $18-27$ years old, which is $77 \%$. The least percentage of respondents came from the group of respondents aged $37-45$ years old, which is $8 \%$. The education level of respondents showed most respondents were Bachelor graduate $(72 \%)$.

Results indicates the percentage of respondents who work as private employees are the highest i.e. $42 \%$. Profile of respondents by domicile can explained that the majority of people who work or frequently commute to Jakarta by private vehicle are people who reside in Jakarta with a percentage rate of $49 \%$.

\subsection{Awareness}

Awareness is the first step of the marketing process and is an introductory stage, where customers get to know about the existence of service (Rowley, 1998). From the results of the survey, respondents were divided into two groups: $47 \%$ of respondents who have already used Waze and $53 \%$ of respondents have not used the Waze application (Table 2). 
INDEPENDENT JOURNAL OF MANAGEMENT \& PRODUCTION (IJM\&P)

http://www.ijmp.jor.br

v. 7, n. 3, July - September 2016

ISSN: 2236-269X

DOI: 10.14807/ijmp.v7i3.447

Table 2: Categories of respondents

\begin{tabular}{lcc}
\hline Categories & $\mathrm{n}$ & $\%$ \\
\hline User of Waze & 94 & 47 \\
Non User & 106 & 53 \\
\hline Total & 200 & 100 \\
\hline
\end{tabular}

It can be seen that the top of mind of mobile navigation application by the respondents is the Google Maps app with a percentage of $56 \%$ of the total respondents and competing with Waze app which ranks second at $44 \%$ of the total respondents. Brand recall is the second model in mind of the respondent after the top of mind. The research results showed that the Waze app ranks first with the percentage of $54 \%$. Then the application Google Maps ranks second in brand recall with the percentage of $43 \%$, hereinafter Sygic ranks third on the percentage of $2 \%$ and the last position is occupied by Pontan backcountry GPS Navigator with a percentage of $1 \%$ (Table 3 ).

Table 3: Composition awareness

\begin{tabular}{|c|c|c|c|c|c|c|}
\hline \multirow[b]{2}{*}{$\begin{array}{c}\text { Mobile navigation } \\
\text { app }\end{array}$} & \multicolumn{3}{|c|}{ Top of Mind } & \multicolumn{3}{|c|}{ Brand Recall } \\
\hline & $\begin{array}{l}\text { User } \\
(n=94)\end{array}$ & $\begin{array}{l}\text { Non User } \\
(n=106)\end{array}$ & $\begin{array}{c}\text { Total } \\
(200) \\
(\%)\end{array}$ & $\begin{array}{l}\text { User } \\
(n=94)\end{array}$ & $\begin{array}{l}\text { Non User } \\
(n=106)\end{array}$ & $\begin{array}{c}\text { Total } \\
(200) \\
(\%)\end{array}$ \\
\hline Waze & 73 & 15 & 44 & 20 & 88 & 54 \\
\hline Google Maps & 21 & 91 & 56 & 71 & 15 & 43 \\
\hline Sygic & 0 & 0 & 0 & 3 & 1 & 2 \\
\hline Pontan & & & & & & \\
\hline $\begin{array}{l}\text { BackCountry } \\
\text { Navigator GPS }\end{array}$ & 0 & 0 & 0 & 0 & 2 & 1 \\
\hline
\end{tabular}

\subsection{Interest}

Interest in a particular business may appear when customers show it in a particular product that he knows (GHIRVU, 2013). The survey results showed that there were 183 respondents who are interested in using Waze application and 17 respondents who are not interested in Waze application. Too complicated and too difficult to use were reason most often voiced by respondents i.e. 53\%. The other reason that makes respondents not interested in using Waze application can be seen in Figure 1. 
INDEPENDENT JOURNAL OF MANAGEMENT \& PRODUCTION (IJM\&P)

http://www.ijmp.jor.br

v. 7, n. 3, July - September 2016

ISSN: 2236-269X

DOI: 10.14807/ijmp.v7i3.447

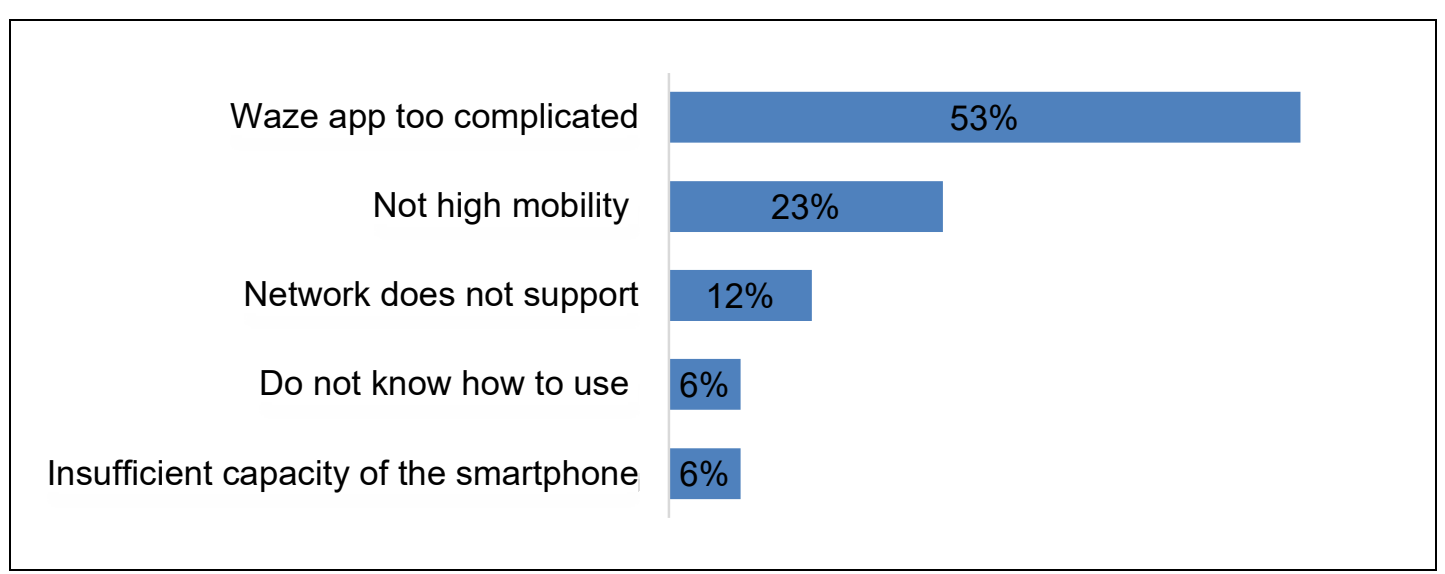

Figure 1: The reason respondents are not interested in using Waze app

Respondents that were interested in using Waze app as a mobile navigation app state their responses to nine statements given (Table 4).

Table 4: Summary of responses to interest Waze app

\begin{tabular}{|c|c|c|c|c|c|c|}
\hline \multirow[t]{2}{*}{$\begin{array}{l}\text { Attributes interest Waze } \\
\text { app }\end{array}$} & \multicolumn{3}{|c|}{$\begin{array}{l}\text { User } \\
(n=94)\end{array}$} & \multicolumn{3}{|c|}{$\begin{array}{l}\text { Non User } \\
(n=89)\end{array}$} \\
\hline & Disagree & $\begin{array}{l}\text { Between } \\
\text { agree } \\
\text { and do } \\
\text { not }\end{array}$ & Agree & Disagree & $\begin{array}{l}\text { Between } \\
\text { agree and } \\
\text { do not }\end{array}$ & Agree \\
\hline $\begin{array}{l}\text { Simple and uncomplicated } \\
\text { to use }\end{array}$ & 2 & 10 & 82 & 4 & 25 & 60 \\
\hline $\begin{array}{l}\text { Guiding the way to avoid } \\
\text { congestion and find a new } \\
\text { address }\end{array}$ & 3 & 13 & 78 & 1 & 15 & 73 \\
\hline Real time information & 7 & 19 & 68 & 0 & 24 & 65 \\
\hline $\begin{array}{l}\text { Can interact with fellow } \\
\text { users }\end{array}$ & 15 & 30 & 49 & 9 & 35 & 36 \\
\hline $\begin{array}{l}\text { Can edit and update the } \\
\text { map }\end{array}$ & 13 & 23 & 58 & 7 & 25 & 57 \\
\hline $\begin{array}{l}\text { Doesn't waste smartphone } \\
\text { capacity }\end{array}$ & 16 & 35 & 43 & 19 & 37 & 33 \\
\hline $\begin{array}{l}\text { Doesn't drain smartphone } \\
\text { battery fast }\end{array}$ & 30 & 34 & 23 & 25 & 35 & 29 \\
\hline $\begin{array}{l}\text { Low use of internet } \\
\text { package quotas }\end{array}$ & 23 & 47 & 24 & 15 & 47 & 27 \\
\hline $\begin{array}{l}\text { Following the trend of } \\
\text { technology }\end{array}$ & 26 & 19 & 49 & 17 & 15 & 57 \\
\hline
\end{tabular}

The attribute with the bigger value that makes the respondents who have not used become interested is that the Waze app can guide the way to avoid congestion and find a new address or point of interest. As for respondents who have already used the Waze app claimed to be interested in the application for the simple or userfriendly and uncomplicated application. 
DOI: 10.14807/ijmp.v7i3.447

\subsection{Desire}

Previous research revealed that desire for action is the best predicting factor for behavioral changes between attention and interest for action (BAHRAM; SHAEMI; JOLODAR, 2011). There were 181 respondents who were interested in the application Waze while 2 respondents were not interested in Waze application. Low mobility so that the application Waze is not necessary is the reason why respondents are not interested in Waze application.

Similar to the interest of respondents, at this stage the respondents who are interested and are willing to use Waze app as a mobile navigation app include their ratings of importance to the nine statements given (Table 5).

Table 5: Summary of responses desire Waze app

\begin{tabular}{|c|c|c|c|c|c|c|}
\hline \multirow[t]{2}{*}{ Attributes desire Waze app } & \multicolumn{3}{|c|}{$\begin{array}{l}\text { User } \\
(n=94)\end{array}$} & \multicolumn{3}{|c|}{$\begin{array}{c}\text { Non User } \\
(\mathrm{n}=87)\end{array}$} \\
\hline & Disagree & $\begin{array}{l}\text { Between } \\
\text { agree and } \\
\text { do not }\end{array}$ & Agree & Disagree & $\begin{array}{l}\text { Between } \\
\text { agree and } \\
\text { do not }\end{array}$ & Disagree \\
\hline $\begin{array}{l}\text { Simple and uncomplicated } \\
\text { to use }\end{array}$ & 5 & 16 & 73 & 4 & 23 & 60 \\
\hline $\begin{array}{l}\text { Guiding the way to avoid } \\
\text { congestion and find a new } \\
\text { address }\end{array}$ & 4 & 17 & 73 & 0 & 12 & 73 \\
\hline Real time information & 6 & 23 & 65 & 1 & 26 & 60 \\
\hline $\begin{array}{l}\text { Can interact with fellow } \\
\text { users }\end{array}$ & 21 & 34 & 39 & 13 & 29 & 45 \\
\hline $\begin{array}{l}\text { Can edit and update the } \\
\text { map }\end{array}$ & 13 & 29 & 52 & 7 & 31 & 49 \\
\hline $\begin{array}{l}\text { Doesn't waste smartphone } \\
\text { capacity }\end{array}$ & 19 & 40 & 35 & 15 & 40 & 32 \\
\hline $\begin{array}{l}\text { Doesn't drain smartphone } \\
\text { battery fast }\end{array}$ & 29 & 38 & 27 & 20 & 38 & 29 \\
\hline $\begin{array}{l}\text { Low use of internet } \\
\text { package quotas }\end{array}$ & 23 & 44 & 27 & 15 & 47 & 25 \\
\hline $\begin{array}{l}\text { Following the trend of } \\
\text { technology }\end{array}$ & 22 & 25 & 47 & 9 & 23 & 55 \\
\hline
\end{tabular}

Of the nine attributes of the statement, there are several attributes that have value with a high level of interest, these attributes are: At the stage of desire, nonuser respondents are interested in using Waze app because Waze app can guide the way to avoid congestion and find a new address or point of interest. The second attribute that makes non-user respondents are interested in using the app Waze is Waze application is simple and uncomplicated and can provide real time information. Last attributes that make non-user respondents are interested in using Waze app is that Waze app follows the trend of latest's technology. Respondents who have 
already used Waze app state that they are interested in Waze application because it is easy and uncomplicated, Waze app can find addresses and lead the way to avoid congestion, and the last reason is Waze app can provide real time information.

\subsection{Adoption}

Adoption is the last stage of the process of adoption of mobile navigation app Waze. At this stage, it was discovered there were seven non-user respondents who were not willing to use the Waze app as a mobile navigation application while driving on the highway. Based on the results of a brief interview with the non-user respondents, five respondents stated the reasons is because they have used and suits with other mobile navigation apps. While the last two respondents who are not willing to use Waze app stated the reason is that they do not really need a navigational tool Waze.

There were 80 non-user respondents who decided to adopt the Waze application with a time difference (Figure 2). $68 \%$ of respondents decided to immediately use the Waze app in less than one week. It is known that the majority of respondents who are willing to use Waze app in less than one week are respondents with the young age, 18-27th years. It is said that young people have great enthusiasm in encouraging trend (KARTAJAYA, 2015). When being grouped, nonuser respondents were included in the category of early adopter. This is because before adopting, respondents wanted more information regarding mobile navigation application Waze.

Furthermore, $16 \%$ of the non-user respondents stated they intended to use Waze application after using the Waze app more than one week. Respondents who intended to use the Waze application for more than a week were included into the category of early mayority. Early mayority group category will compromise carefully before making decision in adopting innovations (ROGERS, 2003).

In addition, there were $8 \%$ of non-user respondents who intended to adopt Waze application within one month. The group of respondents who adopted Waze application within one month were included into late mayority category. Late mayority group typically wait until most people have tried and adopted innovations before they take a decision (ROGERS, 2003). Meanwhile, $8 \%$ of respondents were in the lagards category. Laggard group is the last person to adopt innovation, the group takes more 
DOI: $10.14807 /$ ijmp.v7i3.447

than one month to adopt the Waze app. People who are in this group are usually more traditional and reluctant to try (ROGERS, 2003).

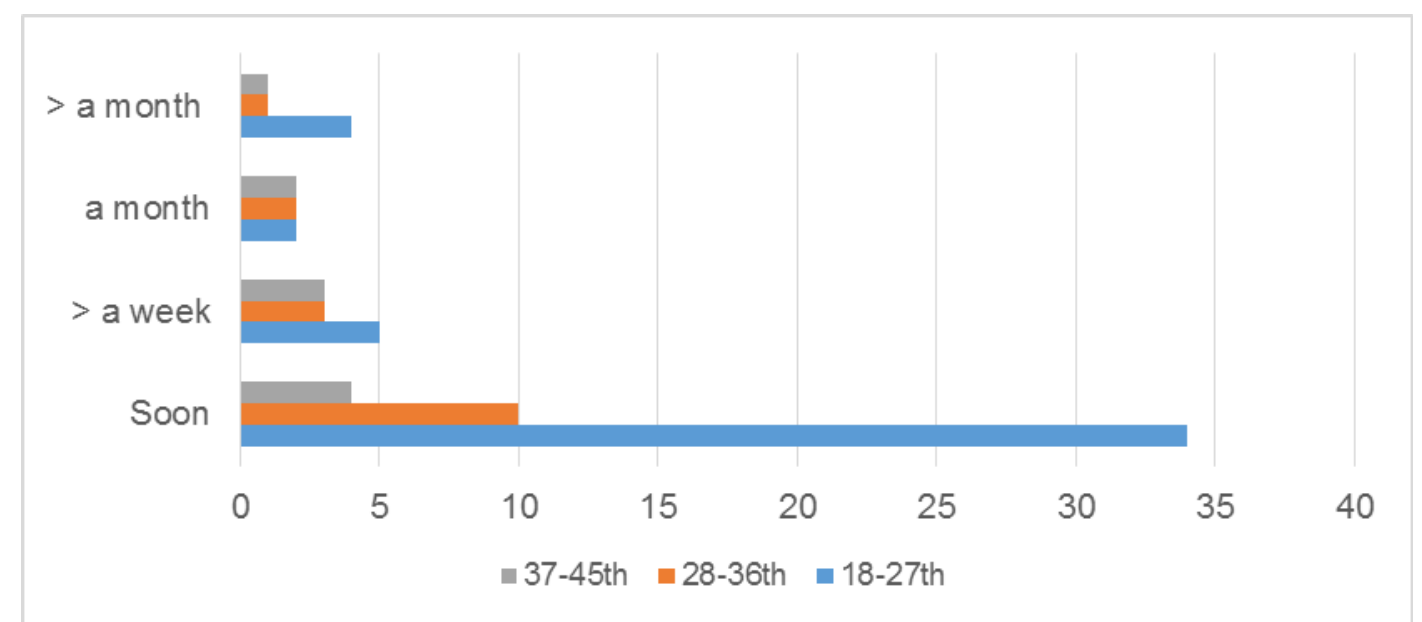

Figure 2: Time required by non-user respondents to adopt Waze app

At the stage of adoption also can be seen there are 7 users who say they will not continue to use Waze application. Reasons why user will not continue using the app Waze are summarized in Figure 3.

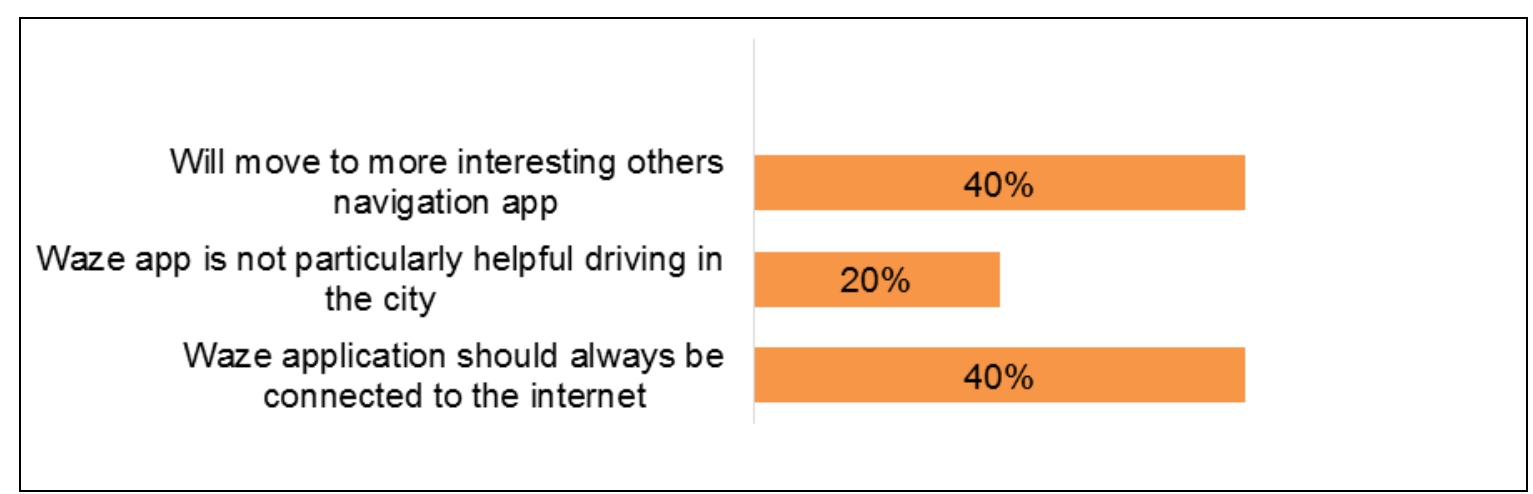

Figure 3: Composition of user reasons that will not continue use the Waze app

The results of the evaluation revealed the majority $53 \%$ of user respondents were satisfied with the Waze app. The next stage which occurs when respondents were satisfied with the product or service is the respondents will promote a product or service to friends or the surrounding environment (WIJAYA, 2012). Based on the results of the study, $84 \%$ of respondents were willing to promote Waze app to friends and the surrounding environment, and the remaining $16 \%$ of respondents were not willing to promote Waze app to friends and the surrounding environment.

\section{DISCUSSION AND CONCLUSION}


DOI: 10.14807/ijmp.v7i3.447

From a series of stages of the adoption process, it can be concluded that in general the respondents were already aware of mobile navigation application Waze, but many respondents were not using this navigation application. Respondents who have not used the Waze app were exposure with information related to Waze app. After being given the exposure of information related to the benefits and functions of the Waze application, the respondent were being interviewed to see the reaction of respondents about the Waze app. Respondents who were aware of the advantages of the Waze application reacted and showed interest and decided to adopt the Waze app while driving. However, not all respondents gave a positive reaction using Waze application. There were some respondents who were not interested in adopting Waze app although the respondents had given exposure information about advantages related Waze application. It was understandable, because the respondents have different preferences.

Similar to the group of non-user respondents, respondents who have already used the Waze app also participate in the interview to see interest and desire in adopting the Waze app. There is no guarantee about people who have already use innovation will continually use the same innovation. In fact, some respondents refused to constantly use the Waze app as a mobile navigation application while driving.

The results showed that each stage of the hierarchy of effects in the model AIDA affects one another. Awareness is able to form respondents interest, the strong interest of respondents have an impact on the high interest of the respondent to adopt Waze application. Strong desire and interest makes the respondents decide to adopt the Waze app as a mobile navigation application while driving in Jakarta and outside Jakarta. There are steps in the reaction of the respondents that are given stimuli lead to action and behavior change to adopt the Waze app. So the more and more people use Waze app while driving, the more accurate the information produced.

\section{REFERENCES}

AGUSTAN. (2008) Sistem navigasi kendaraan bermotor di Jakarta. Majalah Inovasi, v. 10, n. 20. 
BAHRAM, R. et al. (2011) Assessing the effectiveness of electric conservation advertisement in isfahan channel television. International Business Research, $v$. 43, n. 3, p. 194-200.

BELCH, G. E.; BELCH, M. A. (2009) Advertising and Promotion: An Integrated Marketing Communications Perspective, 8th Ed. Boston: The McGraw-Hill.

GHIRVU. A. I. (2013) The AIDA Model for Advergames. The USV Annals of Economics and Public Administration, v. 13, n. 1, p. 90-98.

GROVER, R.; VRIENS, M. (2006) The Handbook of Marketing Research. Thousand Oaks CA: Sage Publication Ltd.

HASAN, J. et al. (2012) Factor analysis in desire to buy environmental friendly products case study for air condition products. International Business Research, v. 5, n. 8.

HENDRATNO, E. T. (2009) Masalah Transportasi Kota Dilihat dengan Pendekatan Hukum, Sosial, dan Budaya. Mimbar Hukum, v. 21, n. 3, p. 409-628.

KARTAJAYA, H. (2015) Marketing in challenging times. Indonesia: Gramedia Pustaka Utama.

LESTARI, W. S. (2012) Evaluasi penggunaan saluran komunikasi antarpribadi sebagai salah satu strategi komunikasi dalam proses adopsi inovasi program pemerintah. (Thesis in Communication). Indonesia: Indonesia University.

MOOIJ, N. D. (2010) What drives the adoption of new technology: the case of iPad. (Thesis in Science Business). Amsterdam: Universiteit van Amsterdam.

MORISSAN, M. A. et al. (2013) Teori komunikasi massa. Indonesia: Ghalia.

REHMAN, F. U. et al. (2014). A comparative analysis of mobile and email marketing using AIDA model. Journal of Basic and Applied Scientific Research, v. 4, n. 6, p. 38-49.

ROGERS, E. M. (2003) Diffusion of Innovation, 5th Ed. New York, US: Free Pr.

ROWLEY, J. (1998) Promotion and Marketing communications in the information marketplace. Library Review, v. 47, n. 8, p. 383-387.

SUTOMO, H. (2008). Reformasi transportasi publik di Jakarta: sebuah kisah sukses. Majalah Inovasi, v. 10, n. 20.

WHITE, D. (2000). Close more sales. United Kingdom: Management Books 2000 Ltd.

WIJAYA, B. S. (2012). The development of hierarchy of effects model in advertising. International Research Journal of Business Studies, v. 5, n. 1. 